\title{
Desire and Curiosity in En Diciembre llegaban las brisas
}

\author{
Santiago Parga Linares / Universidad de los Andes
}

If En diciembre llegaban las brisas (1987), Marvel Moreno’s only published novel, is "about" something, it is certainly a novel about desire. In it, she explores the ways in which desire can liberate or enslave women in a violent and conservative society that tries hard to control it. The novel's unrepentant difficulty, as well as its brutal depiction of the country's misogynistic, racist, prudish, and violent attitudes made it unpopular among readers still swooning after magical-realist depictions of the Caribbean and García Márquez's 1982 Nobel Prize. The novel's protagonist, Lina, serves as a narrator-protagonist and a literary version of Moreno herself who takes the reader on a tour of Barranquilla's society in the 1940s and 1950s through the lives of Dora, Catalina, and Beatriz as intelligent and beautiful women who are pitted against a society that seems designed to crush them.

It is their sexuality (understood as the discovery of their ability to feel and arouse desire) that marks the beginning of their physical and intellectual oppressions. Their relationship to desire is also what serves as a starting point for each of their stories and for the novel as a whole. It is not by chance that very early on, the protagonist's grandmother, a wise and prophetic figure, tells Lina that "Al principio no había sido el Verbo ... porque antes del Verbo había habido la acción y antes de la acción el deseo. En su origen cualquier deseo era y sería siempre puro, anterior a la palabra, ajeno a toda consideración de orden moral" (Moreno 2014, 65).

An important part of the critical attention that the novel has received has focused, and rightly so, on the relationship between nascent sexual desire that Lina's three friends discover and the repression they suffer at the hands of Barranquilla's high society. ${ }^{1}$ And, although sexual desire is an essential part of the universe of En diciembre, it is not the only type of desire that determines the novel's content or gives it its structure.

Divided in three parts, each dedicated to one of Lina's three friends, the novel chronicles the protagonist's emotional and artistic education as she observes how Dora, Catalina, and Beatriz clash with the city's elitist upper echelons. In a recently published interview, Moreno suggests that the novel is structured like a Bildungsroman, as it narrates Lina's "educación espiritual, su evolución, una educación que ha sido posible por las experiencias que ha vivido, por las que han vivido sus amigas y por las reflexiones que sus abuelas y sus tías le han hecho a propósito de estas amigas" (Moreno 2018). Lina's role as a witness who observes, comments and questions (but rarely participates), allows the reader to experience the world through her eyes as she tries to make sense of the way her friends' desire is met with violence. Lina's narration of her friends' experiences and the reflexiones led by her grandmother and aunts appear to be guided by her curiosity, which is the guiding force behind both her education and the novel's overarching structure.

Thus, the purpose here is to show that curiosity, Lina's desire for knowledge and understanding, determines the form of the novel and is the impulse that guides the protagonist's artistic and emotional education. The tension at the heart of the novel, at least for Lina, is not between sexual desire and its repression, but rather between knowing and not knowing. Lina's epistemophilia (broadly understood as love of knowledge) is the novel's structural principle. Her desire-epistemological rather than sexual-is En diciembre's guiding force.

Writing in exile from Paris, Lina embarks on a quest for a deeper understanding of her friends and the society that produced them. Her curiosity is no mere interest in high society gossip or childish inquisitiveness: she seeks satisfaction as intensely and doggedly as her characters seek sexual gratification. This suggests that En diciembre llegaban las brisas is a novel about desire for knowledge as much as it is about sexual desire.

This article will trace the different versions of desire as they play out in the novel through an analysis of psychoanalytical and post-psychoanalytical interpretations of the concept. There is, in Moreno's Barranquilla, a tense relationship between a possessive and violent sort of desire that usually leads to violence and another, perhaps postmodern understanding of it, that attempts to liberate it from guilt. This tension between possession and production; violence and pleasure, can be traced in Lina's education and in her own experience of desire-as-curiosity.

Guided by her grandmother and aunts, Lina eventually understands that knowledge (or truth) and the ultimate objects of her desire are things she simply cannot obtain. By the end of her Bildung, she will come to the realization that "truth" cannot satisfy her curiosity because it simply does not exist. It is only through art, especially writing, that Lina will come to any sort of fulfillment of her curiosity, imperfect as this satisfaction may be. 
In this learning process and her growing understanding of desire, Lina appears to trace the shift from a modern understanding of the world, dominated by Freud, Marx and Nietzsche, to a postmodern world view that allows for the coexistence of conflicting (if not contradictory) interpretations and "the shattering of any single explanatory rationality" (Elston 2015, 819). ${ }^{2}$ The novel's three-part structure mirrors Lina's exploration of curiosity and her quest to satisfy it. Guided by her elders, Lina tries to make sense of her friend's lives as she witnesses Dora's humiliating destruction, Catalina's unlikely escape from Barranquilla's oppressive society, and Beatriz's melodramatic self-destruction. This notion of curiosity-as-desire can allow for a different understanding of Moreno's work and can provide a powerful tool for reading similar narratives with a strong autobiographical component, starting with the recently published and much awaited second novel, El tiempo de las amazonas (2020).

\section{The Nature of Desire in En diciembre llegaban las brisas}

Therefore, it is not surprising that, in a novel about desire, the first and most common object of the protagonist's curiosity is desire itself. During her apprenticeship, Lina comes in contact with two distinct and opposite types which capture her attention. In En diciembre, desire can be a contradictory term, as it is the cause of, and solution to, most of the senseless suffering that takes place in Barranquilla. It can be a liberating force or a crushing power. For some characters, it offers a way out from the city's oppressive atmosphere. The ability to follow their desires, without the guilt or fear associated with them in Barranquilla's violently catholic world, results in a victory of sorts. For others, desire leads only to violence and destruction, self-inflicted or otherwise. My contention here is that Lina simply wants to understand the two types of desire present in the novel. In other words, the object of Lina's curiosity is the nature of desire in En diciembre, and this quest for understanding determines the novel's structure. As such, an initial understanding of desire is necessary here.

On one hand, Lina recognizes a perverse, violent sort of desire. The desiring subject appears to be interested in possessing and controlling the object of their desire. Many female characters and most male characters, including Benito, Álvaro and Javier, husbands to Dora, Catalina and Beatriz, respectively, desire this way and the end result is always some form of violence, usually against women. Lina's first experiences of epistemophilia take place when she comes in contact with this type of desire-as-possession, which is portrayed as a perversion of its purest form.

Dora, for example, the protagonist of the first part, is characterized by an overwhelming exuberance of sexual energy and physical beauty. This exuberance leads to her destruction as the people around her, first her mother and later her husband, attempt to own the desire she feels and elicits. For instance, Eulalia, her mother, upon seeing her powerful (and therefore dangerous) sexuality grow, tries to control it by possessing her daughter and, in doing so, determines the way Dora will be treated as an object of desire by all other characters. The narrator describes the mother-daughter relationship in terms of ownership:

Al principio intentó sofocar, contener o destruir aquella cosa inaudita que Dora rezumaba por cada poro de su piel; al no lograrlo ... trató fascinada de hacerla suya: como una enredadera se le trepó al cuerpo y quiso respirar por sus pulmones, mirar a través de sus ojos, latir al ritmo de su corazón: escudriñó su cerebro con la misma enervada obstinación con la que registraba las gavetas de su tocador y leía las páginas de sus libros y cuadernos: la obligó a pensar en voz alta, a contarle sus secretos, a revelarle sus deseos: terminó por poseerla antes que ningún hombre, abriéndole a todo hombre el camino de $s u$ posesión (Moreno 2014, 30; my emphasis)

Dora feels the destructive effects this attitude brings about throughout her life: first, she is possessed, both physically and mentally, by her mother. Tellingly, the narrator describes the way Eulalia desires her daughter through a language of acquisition, possession, and control, which extends to Dora's external displays of femininity as well as her inner life. Later on, her husband Benito will do the same.

The latter's desire for a wife has more to do with social standing than love or sexual necessity. This requires a woman who is beautiful enough to be desirable, but not so sexually attractive or independent to put his social standing at risk. As the narrator suspects, "A lo que sí aspiraba era a encontrar una virgen, una mujer que le hubiera sido fiel incluso antes de haber nacido para nunca ver su nombre arrastrado al fango, murmurado burlonamente, motivo de escarnio en la ciudad" (Moreno 2014, 76). This will lead him to force Dora to confess every thought she has and despise her own sexuality until she becomes an almost mute shell of herself. Before that, however, he beats her savagely in front of Lina for what he believes to be an unacceptable display of sexuality.

This means that Lina's first brush with the complex, often contradictory manifestations of desire in Barranquilla's high society is marked by violence. In an early passage in which the reader is first introduced to Benito Suárez, the narrator-protagonist describes the moment in which he bursts into her life and piques her interest with his treatment of her friend. Lina finds the violence repulsive and Benito's rage off-putting, but as she observes her friend, bloodied and beaten, she cannot help but be mesmerized by the spectacle. The following passage describes Benito's possessive desire and the curiosity it elicits in Lina: 
Porque Lina lo conocía. Lo había conocido un sábado de carnaval en circunstancias más bien insólitas, aunque este adjetivo, utilizado por Lina deliberadamente al referirle después lo sucedido a su abuela con el fin de no verse acusada de exageración, ni de lejos ni de cerca correspondía a la escandalosa manera como Benito Suárez había surgido ante ella, irrumpiendo en su vida y allí instalándose, pues a partir de ese momento, y dada su amistad con Dora, a Lina no le cupo la menor duda de que aquel hombre iba a cruzar más de una vez su camino y siempre para provocarle el mismo asombro, y a veces, la misma helada rabia que sintió al verle detener su Studebaker en la esquina, salir de él, y perseguir a Dora que ya había descendido con la cara llena de sangre y corría ciegamente hacia la puerta principal de su casa. (Moreno 2014, 20)

Benito, but more specifically his possessive type of desire, bursts into Lina's life and stays there. She will dedicate much time and energy to making sense of it. Although she does not realize it immediately, this event piques her curiosity and becomes a starting point in her education as a woman and as an artist. First, Lina ponders her choice of the adjective she would later use to describe the circumstances to her grandmother. The certainty with which she begins is shattered when the narrator realizes that her choice, insólitas, appears to be altogether inappropriate. As it turns out, Lina does not know Benito (or Dora). She will continue to observe them with a combination of rage and astonishment. Her desire to find the best way to describe the two and their relationship, with the best possible word choice, betrays Lina's eventual outcome as an artist whose primary medium is the written word.

A few pages later, the narrator once again foreshadows Lina's journey from curiosity to understanding. Her first experience with Benito and Dora has propelled her into a journey that will occupy much of her life as she tries to understand not only her friend and her brutish husband, but the nature of desire itself. In this quest, Lina is driven by an epistemophilic desire I have called curiosity:

A Lina le llevó mucho tiempo comprender el alcance de lo ocurrido, en fin, no supo que el simple hecho de haber sido testigo de aquella escena la había cambiado, o más precisamente, había puesto en marcha el mecanismo que de manera irrevocable iba a cambiarla. Fue algo que intuyó después, con los años, al advertir que su memoria conservaba hasta el último detalle de aquel sábado de carnaval en que vio por primera vez a Benito Suárez. (Moreno 2014, 22)

Lina's position as a witness of pointless violence pushes her forward in her apprenticeship. The moment when she comes in contact with the results of Benito's possessive desire, which she finds puzzling, stays with her for the rest of her life. The mechanism that would irrevocably change her is the awakening of her curiosity. Years later, when she still holds a perfect image of the incident in her mind, she realizes that this was the moment in which she started her apprenticeship in decoding the nature of desire.

For Freud, and later for Lacan, desire is - in very broad terms - the result of a lack. This way of seeing desire creates a two-part system in which there is, on one hand, a desiring subject and, on the other, an object of desire. The subject desires something (or someone) because they do not possess it, and their desire can only be fulfilled when that object is acquired.

As understood by Lacan, however, this object of desire is always unattainable and is thus the source of feelings of discomfort, grief, and guilt. All this, at least in En diciembre, leads to some form of violence, sometimes directed at the object of desire, sometimes self-inflicted by the desiring subject. The object-subject relationship can be understood in terms of having and not having: "The object takes the place $\ldots$ of what the subject [is] -symbolically- deprived of .... The opaque character of the objet $a$ in the imaginary fantasy determines it in its most pronounced forms as the pole of perverse desire" (Lacan, Miller, and Hulbert 1977, 15). To put it more simply, Lacan explains that what is "lacking" is not specifically a thing or a person. Instead, lack refers to a fundamental emptiness at the center of the subject's self, a hole that they will attempt, fruitlessly, to fill with a series of objects meant to replace the missing phallus.

As Lacan explains it in one of the seminars, "desire is a relation of being to lack. This lack is the lack of being properly speaking. It isn't the lack of this or that, but lack of being whereby the being exists. This lack is beyond anything which can represent it" (Lacan 1991, 223). This is to say that desire, in this understanding of it, is always defined in negative terms. This lack-based theory of desire also requires it to be understood in terms of possession: "For the subject, of course, it's a question of to have it or not to have it," (Lacan, Miller, and Hulbert 1977, 48 my emphasis). In Moreno's world, this type of desire is felt by men like Benito or women like Eulalia in the passage quoted above; it often victimizes the people involved, both subject and object. Unsurprisingly, in Moreno's world at least, this is a frustrating, unfulfilling, painful, and confounding experience.

Likewise, Lina comes in contact with another type of desire that appears to be free from guilt, envy, and violence. The novel is, in many ways, an apology of desire in its purest, most constructive forms. Lina's grandmother and aunts describe and theorize this type of desire that is devoid of feelings of lack or possession and is thus incapable and uninterested in perpetuating oppressive power imbalances. Characters who desire in this manner are the only ones who manage to escape violence in Barranquilla. 
Divina Arriaga, for example, is a beautiful and liberated socialite who personifies this productive and emancipatory version of desire. Her daughter, Catalina, is the only one of Lina's three friends to escape Barranquilla's oppressive atmosphere, in no small part thanks to her mother's influence. This is how Lina describes Divina: "tomaba: un objeto, un caballo, un hombre, no a fin de poseerlo, pues parecía estar más allá de toda posesión, sino de integrarlo a su vida un instante, el tiempo de posar sobre él su mirada, o cabalgar a través de un bosque o hacer el amor entre sábanas de satín plateado" (Moreno 2014, 159).

Uninterested in possession, control or anything other than momentary, mutual pleasure, Divina transcends the social and religious mores that are commonly used against desire. Hers is concerned exclusively with a momentary experience of pleasure. For the narrator's aunt Eloísa, this is a more honest or pure expression of desire as it has no negative impacts on the desiring subject, the object of desire, or society at large. In each of the novel's three sections, Lina's friends come in contact with this type of liberating desire, but only Catalina is able to experience and follow it freely and is thus the only one who is able to avoid a violent end. Lina too will eventually realize that her curiosity closely resembles this lack-free longing.

This different kind of desire is in keeping with what Deleuze and Guattari propose in Anti-Oedipus. Their work redefines desire in terms that better suit the way in which Lina's curiosity operates in En diciembre. In that book, Deleuze and Guattari question the lack-based theory of desire:

To a certain degree, the traditional logic of desire is all wrong from the very outset ... From the moment that we place desire on the side of acquisition, we make desire an idealistic (dialectical, nihilistic) conception, which causes us to look upon it as primarily a lack: a lack of an object, a lack of the real object. (Deleuze and Guattari 1983, 25)

What they mean by "traditional" here is, of course, a reference to Lacan's work. By proposing that it is better understood as a problem of production, not of fantasies, a problem that takes place in the real and social realms, they create an avenue to better understand the second type of desire in Moreno's work. For Deleuze and Guattari (1983), lack is not something that occurs in the subject, but rather something that takes place in a "deterritorialized space" (35), and, therefore, subjected to a guilt-free experience that is conducive to production. Removed from Barranquilla and all its systems of oppression and control, desire can return to its pure, original form and lead to creation, rather than destruction.

This Deleuzian production-based theory of desire has been adopted by feminist theorists as it removes women from the role of the containers of lack and the men's "other," and allows for a refiguring of desire in more positive terms. Quoting Elizabeth Grosz, Gorton (who has applied psychoanalytic theory to media and film studies) argues the following:

As production, desire does not provide blueprints, models, ideals, or goals. Rather, it experiments, it makes: it is fundamentally aleatory, inventive. Such a theory cannot but be of interest for feminist theory insofar as women are the traditional repositories of the lack constitutive of desire and insofar as the oppositions between presence and absence, between reality and fantasy, have conventionally constrained women to occupy the place of men's other. (Gorton 2008, 25)

Divina, Catalina, and ultimately Lina, as well as a select few minor characters in the novel, manage to experience desire in this way. They are the ones who come closest to something akin to a fulfilling, violence-free existence, devoid of guilt and self-hatred. The novel then, by contrasting these two opposing types of desire, appears to be championing one over the other. In this way, it would appear as if the novel were following Deleuze's proposal for a more "positive" version of desire. Judith Butler explains this opposition between Deleuze and Lacan, useful here as it addresses the novel's feminist bent and places this reading of two versions of desire in line with previous criticism of the novel that finds sexual liberation and the defense of women's jouissance to be an essential part of it.

Deleuze's theory prescribes a move from negative to productive desire which requires that we accept an emancipatory model of desire. In this sense he has politicized the Lacanian theory, arguing that productive desire, jouissance, is accessible to human experience, and that the prohibitive laws governing this desire can and must be broken (Butler 1987, 213).

However, Gorton is quick to point out that understanding it in opposing, dual terms (Lacanian/Deleuzian, destructive/ productive, male/female, modern/postmodern, negative/positive) risks a counterproductive oversimplification (Gorton 2008, 26). Moreno herself would likely find such totalizing definitions suspicious. Instead, what Lina's apprenticeship - and her eventual discovery of her own desire show - is a passage from one to another without a conclusive choice between either. Curiosity, as it will turn out, participates of both kinds of desire, without falling into simple, deceptive dualities.

In En diciembre, curiosity is, at least in part, an expression of this experimental, inventive, positive desire. It is a guiltfree, possession-free impulse that drives Lina and results in the novel she eventually writes about her friends. Like Divina Arriaga, she does not want to own any of the objects of her desire, nor is she trying to alleviate a feeling of lack in her 
sense of self. On the other hand, however, it can be a painful experience, one that results in obsession and unhappiness as it remains impossible to satisfy. Lina will write the novel in an attempt to satiate her curiosity, but years later, living in exile, she feels neither satisfaction nor relief.

Laura Mulvey, who has theorized the notion of curiosity, especially female curiosity, identifies similar dichotomies in the way the latter has been traditionally portrayed. Analyzing the myth of Pandora (and other similar myths in which curiosity is a dangerous, transgressive force), Mulvey describes three themes that commonly appear in narrations of female curiosity:

it involves an active look and one that has been associated primarily, although not of course exclusively, with women; it relates to the enclosed space of secrets that echoes the interior/exterior topography associated with a particular mythology of the feminine; it is experienced almost like a drive with an aim and object to discover something felt so strongly that it overwhelms prohibition or danger. (Mulvey 1996, 61)

Moreno's description of curiosity-as-desire participates of this definition only partially. On one hand, it is very clearly associated with women, one woman especially. In fact, as Lina is a mostly silent witness, curiosity is one of her only defining characteristics, one she does not share with other characters. Secondly, she experiences curiosity just as overwhelmingly and unavoidably as Pandora or Eve. Even though it is not directly described as transgressive, Lina's curiosity depends on her possession of "la palabra," a reclaiming of the power of language that plays an important role in the events of all three sections and which has been described by various other critics as an important concern in the novel and Moreno's other works. ${ }^{3}$ As Mulvey concludes, a specific type of feminine curiosity can "constitute a political, critical and creative drive" $(1996,62)$. This creative and productive side of curiosity fits in well with the version of desire it represents in the novel, closer to Deleuze and Guattari's productive understanding of it than to Lacan's possessive version.

\section{Apprenticeship in the three-part structure}

Lina's curiosity cannot be understood in the topographical terms Mulvey describes. This duality, which can also be understood in terms of presence/absence, surface/depth, known/unknown, appearance/truth, mystery/solution, etc., participates of castration anxiety and is therefore absent from curiosity in the way Moreno understands it. As Lina will learn, towards the end of her Bildung, her curiosity does not uncover secrets or solve puzzles; its objects are not boxes that can be opened to reveal their secrets or signs that she can satisfyingly decipher: even after observing and scrutinizing her friends, Lina can produce no satisfying conclusions about them.

This realization, however, takes time. The following table, adapted from the work of Fabio Rodríguez Amaya (2004), shows how the three-part structure in the novel traces Lina's apprenticeship in curiosity:

\begin{tabular}{|c|c|c|c|c|c|}
\hline PART & FOREBEAR & $\begin{array}{c}\text { SYSTEM } \\
\text { OF } \\
\text { THOUGH }\end{array}$ & PROTAGONIST & $\begin{array}{l}\text { HUSBAND } \\
\text { (POSSESIVE } \\
\text { DESIRE) }\end{array}$ & $\begin{array}{c}\text { LOVER } \\
\text { (PRODUCTIVE } \\
\text { DESIRE) }\end{array}$ \\
\hline PART 1 & $\begin{array}{l}\text { Grandmother } \\
\text { Jimena }\end{array}$ & $\begin{array}{l}\text { Rationalist } \\
\text { fatalism }\end{array}$ & $\begin{array}{c}\text { DORA } \\
\text { (sensuality) }\end{array}$ & $\begin{array}{c}\text { Benito } \\
\text { Murderous doctor }\end{array}$ & $\begin{array}{c}\text { Andrés } \\
\text { Fulfillment of love }\end{array}$ \\
\hline PART 2 & Aunt Eloísa & $\begin{array}{c}\text { Rebellion } \\
\text { and feminism }\end{array}$ & $\begin{array}{l}\text { CATALINA } \\
\text { (wild beauty) }\end{array}$ & $\begin{array}{c}\text { Álvaro } \\
\text { Homosexual } \\
\text { psychiatrist }\end{array}$ & $\begin{array}{c}\text { Native } \\
\text { Fulfillment of love }\end{array}$ \\
\hline PART 3 & Aunt Irene & $\begin{array}{l}\text { Introspection } \\
\text { and art }\end{array}$ & $\begin{array}{c}\text { BEATRIZ } \\
\text { (automaton-like } \\
\text { isolation) }\end{array}$ & $\begin{array}{c}\text { Javier } \\
\text { Materialistic } \\
\text { businessman }\end{array}$ & $\begin{array}{c}\text { Víctor } \\
\text { Fulfillment of love }\end{array}$ \\
\hline
\end{tabular}

Table 1(Rodríguez Amaya 2004) 
Each of the three parts has the same elements and a similar structure: one of Lina's friends who acts as the protagonist for the section, her husband and her lover, and one of Lina's forebears who supplies her with the theoretical and philosophical apparatus she needs to make sense of the relationships she is narrating. In all three sections, Lina, as a keen observer, is exposed to the possessive sort of desire, embodied in each of the husbands. Inevitably, it leads them to harm their wives, other people and themselves. In each section, however, Lina is privy to her friend's experience with a lover who embodies the opposing version of desire. With them, her friends will experience, if only momentarily, a fulfilment of their love. ${ }^{4}$

A final epilogue, written years later from exile, closes the novel. Written in the first person by an aging Lina, it serves to underscore how En diciembre both participates of and problematises the traditional structure of a Bildungsroman. As Ian Gordon explains it, the traditional Bildungsroman traces a linear series of discoveries or epiphanies that lead the protagonist from frustrating ignorance to satisfying maturity (Gordon 2019, 282). This three-part structure does trace Lina's education in the conflicting versions of desire and curiosity, but the epilogue reminds the reader that the conclusion of her Bildung, the discovery of the written word as the mechanism that can satisfy her curiosity, does not bring any sort of lasting relief or gratification.

The grandmother in the first part is described as "una Casandra milenaria, ni excitada ni histérica, ni siquiera realmente Casandra puesto que no se lamentaba de su suerte ni la de los demás, pero cuyas predicciones debían cumplirse inexorablemente" (Moreno 2014, 20). This fatalism, informed by her reading of Freud, the Bible, Nietzsche, and her vast experience in Barranquilla's high society, allows Jimena to see and understand people with such certainty and clarity that, to Lina, seem prophetic. She instantly understands, for example, upon her first meeting with him, the social and cultural forces that will lead to Benito's violence destroying Dora. Jimena's interventions are fatalistic and hint at the inevitability of conflict between desire in its purest form and the cultural and social forces that attempt to control it. This permeates the first part of the novel with a feeling of certainty and inevitability that will be shattered as Lina comes to realize that, at least for her, the world is not as knowable or predictable as it is for Jimena.

In the second part, Lina is guided by her aunt Eloísa. As she understands it, female liberation is the only worthwhile endeavor, and it can only take place through a reclaiming of sexual and intellectual independence. The entire section is dominated by "el tenaz estribillo de tía Eloísa: puesto que a las mujeres se les imponía la castidad a fin de dominarlas, volviéndolas infantiles, dependientes y cobardes, su afirmación en el mundo pasaba necesariamente por la afirmación de la sexualidad." (Moreno 2014, 233). It is no wonder that this section narrates Catalina's liberating affair with a wild, hyper-sexual native, her orchestration of her husband's suicide, and her eventual escape from Barranquilla, which will lead her to become a wealthy and libertated globe-trotting socielite. Like Jimena, Eloísa understands Barranquilla and the role desire plays (and should play) in the lives of its citizens. While this is clear for aunt Eloísa, that certainty does not transfer to Lina.

Lina's grandmother and her two aunts each view the world and the issue of desire differently and each one provides Lina with different insights during her apprenticeship. As Elston points out,

If in the first section of En diciembre she tries to theorize Dora and Benito Suárez's relationship through her grandmother's psychoanalytical or Nietzschean perspective, and in the second section of the novel is influenced by Catalina and Eloísa's feminist politics, it is only in the third section, under the influence of Aunt Irene, that she learns to "ir más lejos de su percepción de las cosas hasta alcanzar una nueva perspectiva" (180). (Elston 2015, 818)

Elston describes the ways in which Lina continually tries and fails to rationalize the events she witnesses according to the framework provided by her grandmother and aunts. This failure, particularly in the first and second parts of the novel, is an essential component of her apprenticeship. As Lina tries out the Bible/Psychoanalysis framework in the first part and the Feminist/Revolutionary in the second section, she fails to understand how these ideologies explain the nature of desire and the impact they have on the people who experience it. The first two parts of the novel are especially disappointing for Lina because she cannot achieve the level of certainty of her forebears.

Finally, the third section is governed by aunt Irene. A musician, she is the only artist in the family and provides Lina with the only semblance of satisfaction she will experience in her apprenticeship. Irene shows Lina that her desire has more to do with her relationship with signs than with a fatalistic understanding of society, as Jimena sees it, or an agonistic battle of the sexes, as aunt Eloísa believes. Under Irene's tutelage, Lina understands that her role in this story is not to mediate between desire and fulfillment or desire and repression but between curiosity and discovery, between witnessing and understanding.

It is not until the third and final part, under the guidance of her aunt Irene, that she begins to recognize that the certainty with which Jimena and Eloísa understand their world is impossible to replicate. With Irene, Lina discovers that her role in this story is not to possess or control any version of "truth" regarding her friends or the nature of desire in Barranquilla. Instead, Irene teaches her that there can never be such a thing as "truth." As Elston cleverly points out, this 
disappointment in the possibility of truth and the grand metanarratives of modernity (that underpin Jimena and Eloísa's world views) leads to Lina's eventual discovery of a more postmodern point of view that she, nonetheless, cannot adopt fully.

Speaking with Irene, Lina tries to understand her friend Beatriz, the focus of the third and final part of the novel. Beatriz appears to have internalized every lesson about guilt and shame society has taught her. In one scene, Lina spies Beatriz torturing her dolls for committing some unspecified sin. Perplexed by this behavior, which she assumes has something to do with the struggle between Beatriz's incipient sexual urges and the social and cultural apparatus that has been set up to control them, Lina consults her aunt about the sins that Beatriz "no puede mencionar:"

'Que no sabe mencionar', le oiría ... sugerir a tía Irene sin alzar los ojos del inmenso Libro de los Muertos cuyos jeroglíficos le había estado mostrando a fin de enseñarle el modo de descifrarlos, ... como si creyera a Lina capaz de ir más allá de las apariencias buscando la significación exacta detrás de la oscuridad del signo, a la manera en que aprendía a encontrar sentido de las complejas figuras del libro abierto sobre la mesa. (Moreno 2014, 295)

Almost mockingly, Irene suggests that the problem is not that Beatriz is a prude, but that she is ignorant. If she could only understand her desire, if she had the words to name it or at least the will to understand it, it would not trouble her so violently. The presence of the Book of the Dead in this scene is not coincidental. What Lina needs is not another system that purports to have access to the truth, as is the case with Jimena's prophetic fatalism or Eloísa's revolutionary feminism; what she needs is a system based on the deciphering of signs. Beatriz, Irene appears to suggest, is a hieroglyph like the ones in her book, one which Lina should try to decipher, even if, after doing so, the sign reveals no satisfying or fulfilling truth.

Here, Lina understands how her role as a witness relates to the desire that has been driving her since the moment Benito Suárez burst violently into her life. What Lina wants is simply to understand her friends and thus, understand desire and its effects in society. She also realizes that curiosity is a desire that cannot be satisfied, and thus that it cannot allow for a completely successful deciphering of signs. Wanting to possess a conclusive understanding would only lead to frustration and violence. As a productive kind of desire, curiosity leads Lina to become an artist herself.

Desde entonces, Lina vería la desazón transformarse en curiosidad ... De ese modo, Beatriz se convertiría muy pronto para Lina en fuente de observación, no obstante el rechazo instintivo que su presencia siempre le produjo. (Moreno 2014, 296)

This is an important realization regarding curiosity. It is, in a way the culmination of Lina's apprenticeship. With Irene she learns that the only possible answer she can give to Beatriz's bizarre behavior, Benito's repulsive and uncontrollable rage, and every other display of brutality and violence she encounters, is a type of curiosity that is not interested in possessing or controlling. Even when confronted with a sign begging to be deciphered, she realizes that she must not attempt to break it open or discover some hidden, complete nugget of truth hidden within. Instead, she must take each experience like Divina Arriaga takes a man or a horse: without guilt, violence or the expectation of possession; a momentary grasp that produces more signs instead of destroying them. That is to say, she must write a novel.

Thanks to Irene and her tutelage in the way of signs, Lina understands that the only thing that can satiate her curiosity is the production of more signs, the writing of the novel she will dedicate to her friends. In fact, the system of knowledge that Irene is proposing in the third part of the novel is that of artistic creation:

Con los años Lina comprendería que el simple hecho de vislumbrar aquellos espejismos había modificado su concepción de la vida al sugerirle la existencia de la incertidumbre. Tía Irene y el jardín, los sueños y sus sombras terminarían haciendo añicos la estructura de reflexión que su abuela le había ofrecido como modelo. Mucho más tarde. (Moreno 2014, 363)

Even if truth and complete knowledge are impossible, as Lina suspects very early on in the novel, the act of searching for them provides some hope. In fact, Lina realizes that the way to reconcile the inevitable disappointment of curiosity with her production-based desire is the act of writing. As Téllez (1997) suggests, this is where the narrator's privileged position can be found, "en la reconciliación de sí misma en la escritura" (166). The system of knowledge embodied by aunt Irene is precisely that of art and creation, the result of a productive desire. This is what allows Lina to "ir más lejos" (180). Thus, it comes as no surprise that this is the system that closes the novel and comes back again in the Epilogue. After sampling the three systems that might aid her in her apprenticeship of curiosity, Lina chooses the one that most overtly acknowledges that truth is impossible, that the creation of further signs in art is the only possible path, and that this path is the one that better aligns curiosity with a productive version of desire. This realization will come in the Epilogue, the only part of the book written in the first person. Lina, an old and sick woman living in Paris, becomes a novelist. 
The result of her apprenticeship, the closest she will come to satisfying her curiosity, is the act of writing. Elston indicates that

En diciembre balances the idea of modernity as the culmination of reason, freedom and progress with the crisis and destructiveness of modernity ... Furthermore, this extends into a postmodern questioning of all metanarratives; as represented by Aunt Irene's "escepticismo ante cualquier ideología que pretendiera monopolizar la verdad" (Elston 2015, 809).

This suggests that the epilogue serves as the culmination of the process of curiosity that is doomed to failure if the expected outcome is, as Jimena and Eloísa seem to think, the result of a modern understanding of reason, progress or revolution, the great metanarratives of twentieth-century modernity. But as Lina discovers aunt Irene's skepticism, she also realizes that art and the creation of further signs is the best satisfaction she can hope for.

In this way, En diciembre llegaban las brisas approaches postmodernism from a unique perspective in Colombian literature at that time. The novel has, at its center, the discovery that any system that attempts to control or understand desire or that purports to have access to any form of "truth" is inherently suspicious and more often than not leads to oppression and violence. The novel is the result of Lina's productive, positive desire for knowledge and understanding. Although it fails to reach any grand conclusion about the nature of desire, the position women hold in Barranquilla's high society or the relationship between power, desire, and sexuality, it does provide an account of the connection between curiosity (the type of desire that moves the narrative forward) and language. Just as Lina suspected from the moment she first met Benito, she struggles to find the right words to describe his violence, and just as all three of her forebears suggested, language - and the power to use it - is the end goal of Lina's apprenticeship.

Thus, a novel dedicated to desire is structured by the protagonist's desire. The form of the Bildungsroman traces the evolution of Lina's epistemophilia and concludes with the realization that it simply cannot be satisfied. While Lina comes in contact with two seemingly opposing types of desire and guided by her grandmother and aunts, the novel's three-part structure tracks the protagonist's education and the evolution of her curiosity. The only and best result of curiosity is writing.

\section{Works Cited}

Barbisotti, Barbara. 2008. "La Jerarquía de Las Voces Narrantes En En Diciembre Llegaban Las Brisas de Marvel Moreno." In El Grupo de Barranquilla: Gabriel García Márquez, Un Maestro Marvel Moreno, Un Epígono, edited by Fabio Rodríguez Amaya, 177-91. Bergamo: Bergamo University Press.

Butler, Judith. 1987. Subjects of Desire: Hegelian Reflections in Twentieth-Century France. New York: Columbia University Press.

Deleuze, Gilles, and Felix Guattari. 1983. Anti-Oedipus: Capitalism and Schizophrenia. Minneapolis: University of Minnesota Press,.

Elston, Cherilyn. 2015. “'Ni Engels, Ni Freud, Ni Reich’: Narratives of Modernity in Marvel Moreno's En Diciembre Llegaban Las Brisas (1987).” Bulletin of Hispanic Studies (1475-3839) 92 (7): 805-23. https://doi.org/10.3828/bhs.2015.48.

Gómez de Gonzáles, Blanca Inés. 1997. "La Palabra Como Reescritura Del Destino.” In La Obra de Marvel Moreno: Actas Del Coloquio Internacional, edited by Jacques Gilard and Fabio Rodríguez Amaya. Viareggio : M. Baroni, c1997.

Gordon, Ian. 2019. "Bildungsromane and Graphic Narratives." In A History of the Bildungsroman, edited by Sarah Graham. Cambridge, UK ; Cambridge University Press. https://search.ebscohost.com/login. asp ? direct $=$ true \&scope $=$ site $\& \mathrm{db}=$ nlebk $\& d b=$ nlabk\&AN $=1948872$.

Gorton, Kristyn. 2008. Theorising Desire: From Freud to Feminism to Film. Basingstoke: Palgrave Macmillan UK.

Lacan, Jacques. 1991. The Ego in Freud's Theory and in the Technique of Psychoanalysis. Edited by Jacques-Alain Miller. Translated by Sylvana Tomaselli. New York, N.Y: W. W. Norton \& Company. 
Lacan, Jacques, Jacques-Alain Miller, and James Hulbert. 1977. "Desire and the Interpretation of Desire in Hamlet." Yale French Studies, no. 55-56: 11-52.

Moreno, Marvel. 2014. En Diciembre Llegaban Las Brisas. Bogotá: Alfaguara.

. 2018. Una entrevista inédita de 1988 con Marvel Moreno Interview by Fabio Rodríguez Amaya. https://www. revistaarcadia.com/libros/articulo/entrevista-inedita-con-marvel-moreno-fabio-rodriguez-literatura-colombianasexualidad/69660.

Mulvey, Laura. 1996. Fetishism and Curiosity. Perspectives. London: British Film Institute.

Pezzoli, Francesca. 2008. "Patriarcado y Juegos de Poder En En Diciembre Llegaban Las Brisas.” In El Grupo de Barranquilla: Gabriel García Márquez, Un Maestro Marvel Moreno, Un Epígono, edited by Fabio Rodríguez Amaya, 223-44. Bergamo: Bergamo University Press.

Prandoni, Mauro. 2008. “Control Social y Saber Femenino En En Diciembre Llegaban Las Brisas.” In El Grupo de Barranquilla: Gabriel García Márquez, Un Maestro Marvel Moreno, Un Epígono, edited by Fabio Rodríguez Amaya, 245-60. Bergamo: Bergamo University Press.

Rodríguez Amaya, Fabio. 2004. "La Narrativa de Marvel Moreno: El Poder y La Palabra.” Caravelle (1988-), no. 82: $143-63$.

Téllez, Freddy. 1997. "Los Incipit de En Diciembre Llegaban Las Brisas.” In La Obra de Marvel Moreno : Actas Del Coloquio Internacional, edited by Jacques Gilard and Fabio Rodríguez Amaya. Viareggio : M. Baroni, c1997.

\section{Notes}

1. See Osorio, Gómez de Gonzáles, and especially Araujo for other critical work focused on the role of sexual desire and sexual repression in Moreno's works. Blanca Gómez de Gonzáles, for example, suggests that "El universo narrativo de Marvel Moreno se cifra en tres elementos recurrentes: el erotismo, la abyección y el enjuiciamiento de la sociedad" $(1997,139)$.

2. See Elston (2015) for a more complete discussion on the relationship between the novel and the categories of modernity and postmodernity. Elston argues that, since En diciembre is "fundamentally formed by narratives of modernity and their critiques [...], the novel complicates the idea of an epochal shift from modernity to postmodernity, which in Latin American literary terms is often uncritically seen as synonymous with the transition from the Boom to the post-Boom" (821).

3. See for example: "Los ejes de una crítica social que la novela parece asumir como propia [son] la represión sexual vista como instrumento de poder, el monopolio de la palabra por parte de los hombres; la explotación del saber para la conservación del estatus quo. Los antídotos contra esta sociedad patriarcal son evidentes: la recuperación de la sexualidad reprimida y la reapropiación de la palabra por parte de las mujeres" (Barbisotti 2008, 185). Or "El hombre somete a la mujer precisamente gracias al discurso, a la palabra que se hace poder: al negarle a ella el acceso a ésta última y a la satisfacción del deseo, también le niega la posibilidad de construirse como sujeto ... la única subversión posible: el deseo, la feminidad, la sexualidad" (Pezzoli 2008, 224).

4. As Prandoni understands them, "Lo que vincula estrechamente a Lina con las parientas mayores ... es su proponerse como mentoras más que como maestras. En lugar de imponer un patrón de pensamiento definido por una experiencia en parte incomprensible y en vías de transformación ... sus intervenciones están dirigidas a crear un deplacement cognitivo, a crear una suerte de espacio de la indeterminación que funcione como estímulo del pensamiento" (Prandoni 2008, 255). This suggests that they do not seek to impose a particular way of thinking but rather offer theoretical tools which Lina can take or leave. 